Muh Aris Marfai, dkk. : Pemodelan Spasial Bahaya Banjir Rob Berdasarkan Skenario.....

\title{
PEMODELAN SPASIAL BAHAYA BANJIR ROB BERDASARKAN SKENARIO PERUBAHAN IKLIM DAN DAMPAKNYA DI PESISIR PEKALONGAN
}

\author{
Muh Aris Marfai ${ }^{1}$, Djati Mardiatno ${ }^{2}$, Ahmad Cahyadi ${ }^{3}$, Fitria Nucifera ${ }^{4}$ \\ dan Hari Prihatno ${ }^{5}$ \\ 1,2,3Jurusan Geografi Lingkungan Fakultas Geografi Universitas Gadjah Mada Yogyakarta \\ ${ }^{4}$ Magister Perencanaan Pengelolaan Pesisir dan Daerah Aliran Sungai (MPPDAS) \\ Fakultas Geografi Universitas Gadjah Mada Yogyakarta \\ ${ }^{5}$ Pusat Penelitian Pengembangan Sumberdaya Laut dan Pesisir (P3SDLP) \\ Kementrian Kelautan dan Perikanan Republik Indonesia \\ Email: ㅁarismarfai@yahoo.com,
}

\begin{abstract}
Tidal flood is predicted to be more severe in the future because of sea level rise due to global warming. Purposes of the study are: 1) identify spatial distribution of tidal flood hazard in Pekalongan coastal area; 2) identify environmental impacts of tidal flood in Pekalongan coastal area; and 3) formulate coastal management based on spatial distribution analysis and tidal flood impacts in Pekalongan. Flood analysis in coastal area was conducted by flood hazard mapping using GIS (Geographic Information System). Flood hazard mapping was developed by integrating GIS operation with DEM (Digital Elevation Model), level of inundation and iteration process. Tidal flood inundation scenario was generated based on highest tides and sea level rise scenario by IPCC 2007, level of inundation reached up to $135 \mathrm{~mm}$. Results of this study showed that settlement and irrigated paddy fields are the widest inundated area by tidal flood. Tidal flood provides serious environmental impacts such as infrastructure damage, agriculture and aquaculture land damage, and soil and water pollution. Infrastructure damages include road, settlements and sanitation.
\end{abstract}

Keywords: tidal flood, environmental impact, coastal management, spatial modelling, climate change scenario

\section{Pendahuluan}

Lingkungan pesisir merupakan lingkungan yang sangat dinamis dengan berbagai penggunaan lahan yang sangat komplek (Marfai dan King, 2008a; Aerts et al, 2009; Marfai 2011). Indonesia sebagai negara kepulauan mempunyai daerah pesisir yang sangat strategis yang dapat dioptimalkan untuk mendukung pelaksanaan pembangunan. Banyak perkotaan dan kawasan strategis di Indonesia yang terletak di kawasan pesisir, seperti Jakarta, Semarang, dan Surabaya (Marfai dan King, 2008b; Ward et al, 2010). Namun demikian, disisi lain, kawasan pesisir juga merupakan kawasan yang sangat rawan untuk terkena bencana (Marfai dan King, 2008c; Mardiatno et al, 2007a; 2008a; 2008b; 2009; Marfai et al, 2009). Salah satu bencana yang terjadi di kawasan pesisir adalah bencana banjir (Mardiatno, 2007; Blackett dan Hume, 2007). Banjir kawasan pesisir (rob) dimasa yang akan datang dapat menjadi semakin besar dengan adanya fenomena kenaikan muka air laut akibat pemanasan global. Naiknya muka air laut (sea level rise) merupakan salah satu permasalahan penting yang harus dihadapi oleh negara-negara pantai atau negara kepulauan di dunia (Kobayashi, 2003). IPCC (2007) menyebutkan bahwa kenaikan muka air laut di dunia pada Tahun 2100 akan bertambah sekitar $18 \mathrm{~cm}$ sampai dengan $59 \mathrm{~cm}$. Hal ini berarti pertambahan kenaikan muka airlaut akan 
berkisar antara $0,21 \mathrm{~cm} /$ tahun sampai dengan 0,68 $\mathrm{cm} /$ tahun, atau dengan rerata sekitar $0,44 \mathrm{~cm} /$ tahun. Gambar 1. menunjukkan bahwa trend data pasang surut di beberapa stasiun pengukuran di Laut Jawa menunjukkan adanya trend kenaikan muka air laut. Berdasarkan gambar tersebut (Aldrian dkk, 2011), maka diketahui bahwa kenaikan muka air laut di Jakarta adalah sekitar $0,69 \mathrm{~cm} /$ tahun. Hasil pengukuran yang hampir sama disampaikan oleh Purnama, dkk (2009) yang menyatakan bahwa kenaikan muka air laut di Jakarta adalah sekitar 0,60 $\mathrm{cm} /$ tahun. Fenomena alam ini perlu diperhitungkan dalam semua kegiatan pengelolaan wilayah pesisir (Christanto, 2010, Mardiatno dkk, 2007b). Naiknya suhu air permukaan laut akan diikuti oleh pemuaian massa air laut. Fenomena tersebut, dikombinasikan dengan kontribusi mencairnya lapisan es, menyebabkan percepatan naiknya kedudukan muka air laut atau sea-level rise (IPCC, 2001; Kumar, 2006; Prihatno, 2011).

Banyaknya fenomena banjir pesisir atau biasa disebut banjir rob, pada kawasan pesisir Utara Pulau Jawa saat ini, kemungkinan merupakan salah satu akibat dari perubahan muka air laut karena pemanasan global (Marfai, 2011). Pemanasan global mengakibatkan dampak yang luas dan serius bagi lingkungan bio-geofisik, seperti kenaikan muka air laut, peningkatan hujan dan banjir, perubahan iklim, punahnya flora dan fauna tertentu, migrasi fauna dan hama penyakit, dan sebagainya (IPCC, 2007). Adapun dampak bagi aktivitas sosial-ekonomi masyarakat meliputi: (a) gangguan terhadap fungsi kawasan pesisir dan kota pantai, (b) gangguan terhadap fungsi prasarana dan sarana seperti jaringan jalan, pelabuhan dan bandara (c) gangguan terhadap permukiman penduduk, (d) pengurangan produktivitas lahan pertanian, (e) peningkatan risiko wabah penyakit, dan sebagainya (Nicholls et al, 2000).

Pesisir Pekalongan merupakan salah satu kawasan pesisir utara Pulau Jawa yang saat ini selalu menghadapi bencana pesisir berupa banjir dan genangan. Analisis bencana banjir rob penting dilakukan dalam kaitannya dengan pengelolaan pesisir terpaduan untuk menunjang pembangunan daerah (Kraas, 2007; Ward et al, 2010). Pemodelan genangan dan identifikasi permasalahan lingkungan merupakan salah satu upaya awal dalam menyusun rencana pengelolaan pesisir yang berbasis bencana pesisir (Ward et al, 2009). Penelitian ini bertujuan untuk (1) mengidentifikasi sebaran spasial bahaya banjir genangan di Pesisir pekalongan, (2) mengidentifikasi dampak lingkungan banjir genangan (rob) di Pesisir Pekalongan, dan (3) merumuskan pengololaan pesisir berbasis analisis distribusi spasial bahaya dan dampak banjir rob di Pesisir Pekalongan.

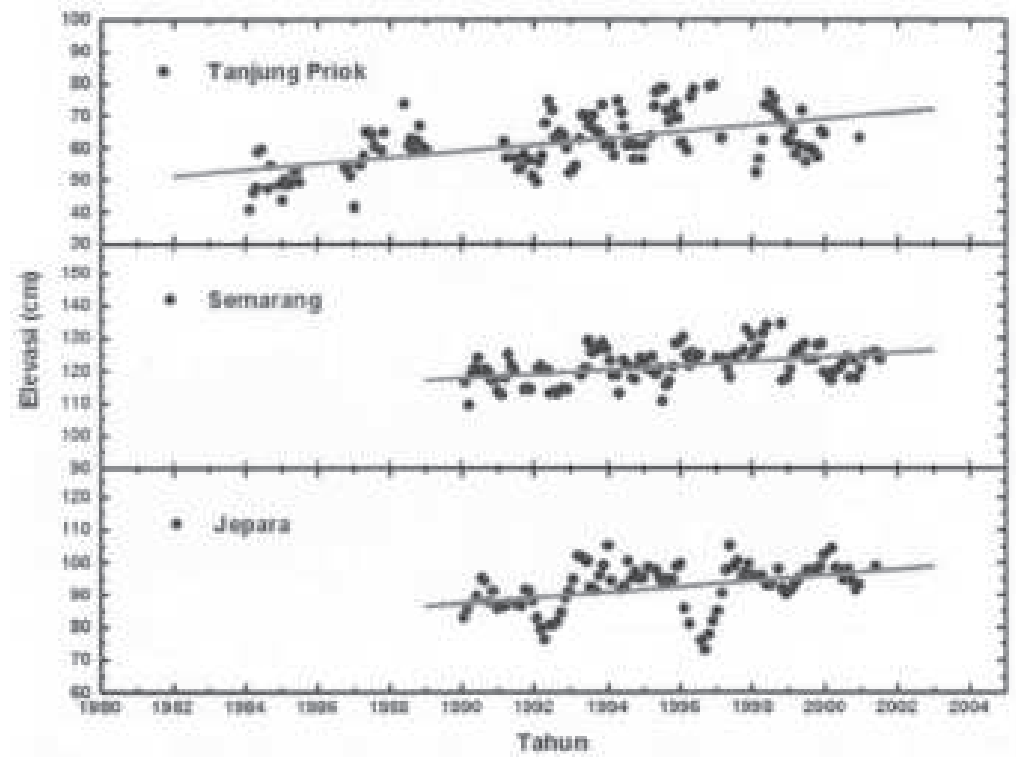

Gambar 1. Trend kenaikan muka air Laut di beberapa stasiun pengukuran di Laut Jawa 


\section{Metode Penelitian}

Persebaran bencana banjir rob di pesisir Pekalongan akan ditunjukkan dengan peta genangan banjir. Peta genangan banjir rob di Pekalongan disusun dengan menggunakan peta dasar berformat raster yaitu DEM (Digital Elevation Model) yang disusun berdasarkan 75 titik pengukuran elevasi dsn dsts dsri peta Rupa Bumi Indonesia (RBI). DEM berfungsi untuk menampilkan informasi ketinggian atau elevasi daerah penelitian (Kresch et al, 2002; Demerkisen et al, 2006). Data DEM ini merupakan data dasar untuk membuat peta genangan banjir daerah penelitian.

DEM berasal dari titik ketinggian permukaan tanah dari peta RBI dan pengukuran lapangan yang kemudian diinterpolasi. Data elevasi daerah penelitian hanya bersifat sebagian sehingga tidak setiap titik di permukaan tanah dapat diketahui elevasinya (Mills et al, 2005). Interpolasi berfungsi untuk melakukan estimasi titik di permukaan tanah yang tidak memiliki data elevasi. Nilai elevasi suatu titik ditentukan oleh nilai titik elevasi daerah di sekitarnya. Dalam hal ini, setiap data elevasi memiliki korelasi spasial dengan data elevasi di sekitarnya. Titik-titik yang berdekatan akan lebih berpengaruh daripada nilai-nilai yang berjauhan (Burrough dan

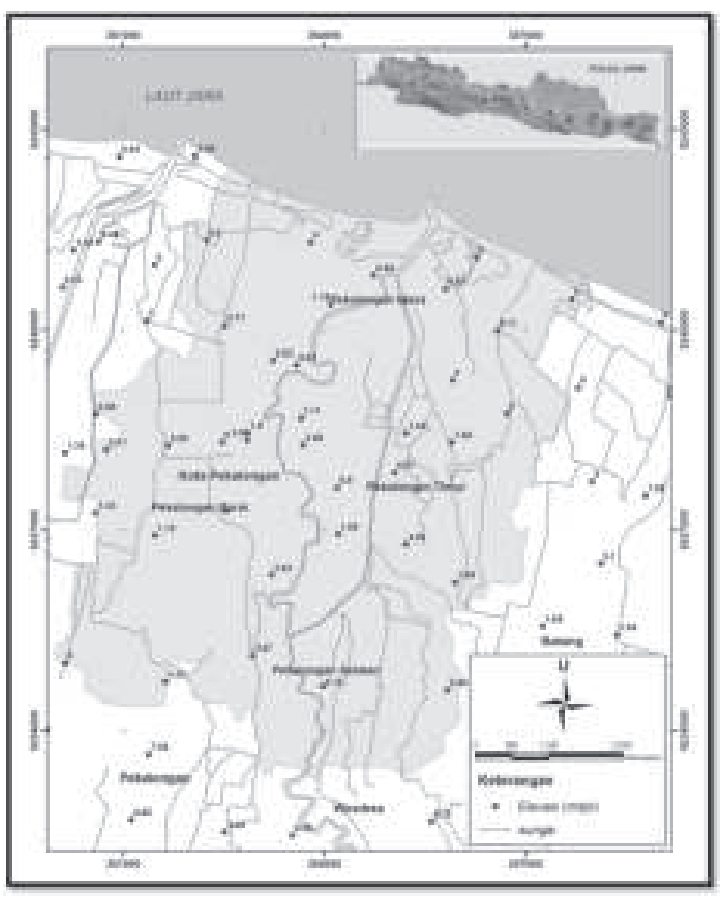

Gambar 2. Peta Titik Elevasi Kota Pekalongan
McDonnell, 1998). Data titik elevasi pesisir pekalongan disajikan dalam Gambar 2. Data elevasi pesisir Pekalongan berkisar antara $0-11,02$ meter dengan rata-rata elevasi 2,25 meter di atas permukaan air laut.

Metode interpolasi yang digunakan dalam penelitian ini adalah metode moving average. Prinsip metode interpolasi adalah menghitung titik yang tidak ada data dengan rata-rata data yang berada di dekatnya. Data elevasi di pesisir Pekalongan tergolong seragam dan terdistribusi secara merata sehingga metode interpolasi moving average dianggap tepat digunakan dalam penelitian ini (ILWIS, 2001). Borough dan McDonnell (1998) merumuskan fungsi interpolasi sebagai berikut :

$\hat{Z}(x)=\frac{\left[\sum_{i=1}^{n} Z\left(x_{i}\right)\right]}{n}$

Keterangan:

$\mathrm{Z}\left(\mathrm{x}_{\mathrm{i}}\right)$ adalah nilai pengukuran pada titik $\mathrm{i}$

$\mathrm{Z}$ (x) adalah nilai yang akan diestimasi pada titik $\mathrm{x}$

$\mathrm{n}$ adalah banyaknya data pengukuran

Pemetaan persebaran genangan banjir di pesisir Pekalongan dilakukan menggunakan proses iterasi (iteration) menggunakan operasi ketetanggaan/ tetangga terdekat (neighbourhood operation). Iterasi merupakan salah satu tipe dari map calculations. Proses ini merupakan pengulangan operasi matematika secara berturut-turut dengan menggunakan satu hasil perhitungan sebagai input untuk perhitungan selanjutnya. Perhitungan dilakukan melalui piksel per piksel. Proses iterasi raster merupakan pemodelan perhitungan menggunakan sistem loop dan memiliki sistem perulangan hingga mencapai kondisi yang dingiinkan. Dalam proses iterasi ini nilai raster DEM dievaluasi. DEM merupakan data utama yang digunakan dalam proses iterasi untuk pemodelan genangan banjir. Neighbourhood operation merupakan analisis spasial khusus yang menghitung nilai piksel berdasarkan nilai piksel tetangganya. Proses ini akan dilakukan pada nilai piksel yang dipilih. Nilai DEM dimodifikasi sedemikian rupa sehingga mendekati kenyataan di lapangan. Modifikasi nilai DEM dilakukan pada penggunaan lahan tubuh air. Garis pantai diasumsikan memiliki nilai DEM nol (0) karena diasumsikan memiliki nilai ketinggian yang sama dengan lautan. Proses iterasi 
dilakukan untuk melakukan estimasi sebaran daerah genangan di mana model yang dihasilkan akan mendekati kenyataan di lapangan. Asumsi yang digunakan dalam model ini adalah bahwa kenaikan muka air laut akan berpengaruh terhadap tubuh air yang berhubungan langsung dengan laut (Marfai et al, 2008).

Proses iterasi dilakukan pada software ILWIS 3.3 Academic version. Pemodelan yang dilakukan dalam penelitian ini bebasis data raster (Marfai, 2003; 2004). Perhitungan iterasi dimulai dari perambatan air ke daratan melalui garis pantai. Garis pantai pada peta digunakan sebagai batas antara daratan dan lautan dengan nilai elevasi 0 meter di atas permukaan air laut. Proses perambatan air laut akan berhenti ketika mencapai pada batas elevasi yang ditentukan. Iterasi pada software ILWIS dilakukan dengan menuliskan script command pada command line sesuai dengan skenario yang diinginkan (Gambar 3). Setelah itu DEM akan diiterasi menjadi model genangan dengan skenario yang telah ditentukan. Sebagai contoh misalnya skenario banjir $120 \mathrm{~cm}$, maka daerah yang tergenang adalah yang memiliki elevasi kurang dari $120 \mathrm{~cm}$.

Identifikasi dampak lingkungan akibat banjir pesisir Pekalongan dilakukan dengan metode superimposed yaitu dengan menampalkan peta skenario genangan dengan peta penggunaan lahan. Berdasarkan hal tersebut, maka dapat diketahui berapa luasan penggunaan lahan yang tergenang pada masing-masing skenario genangan. Evaluasi dampak banjir rob terhadap lingkungan pesisir di Pekalongan dilakukan dengan survei lapangan. Permasalahan dan dampak banjir rob diidentifikasi melalui transek lapangan di kawasan pesisir. Analisis dilakukan secara deskriptif dilakukan untuk merumuskan pengelolaan kawasan pesisir di Pekalongan. Rencana pengelolaan didasarkan pada data sebaran spasial genangan rob dan data dampak lingkungan yang terjadi akibat banjir rob.

\section{Hasil dan Pembahasan \\ 3.1 Pemodelan Genangan Banjir}

Pekalongan merupakan daerah di pesisir yang rawan terhadap kejadian bencana banjir rob. Berdasarkan berita terbaru dilansir dari Media Indonesia, banjir rob pada 6 Mei 2012 merendam delapan kelurahan di Kota Pekalongan, mengakibatkan kelumpuhan pelabuhan, kerusakan permukiman dan kerusakan areal permukiman (Gambar 4a dan Gambar 4b). Berdasarkan hasil wawancara dengan warga setempat, rata-rata banjir rob sekitar $10-50 \mathrm{~cm}$ dan ketinggian maksimal $70 \mathrm{~cm}$ (Gambar 4c).

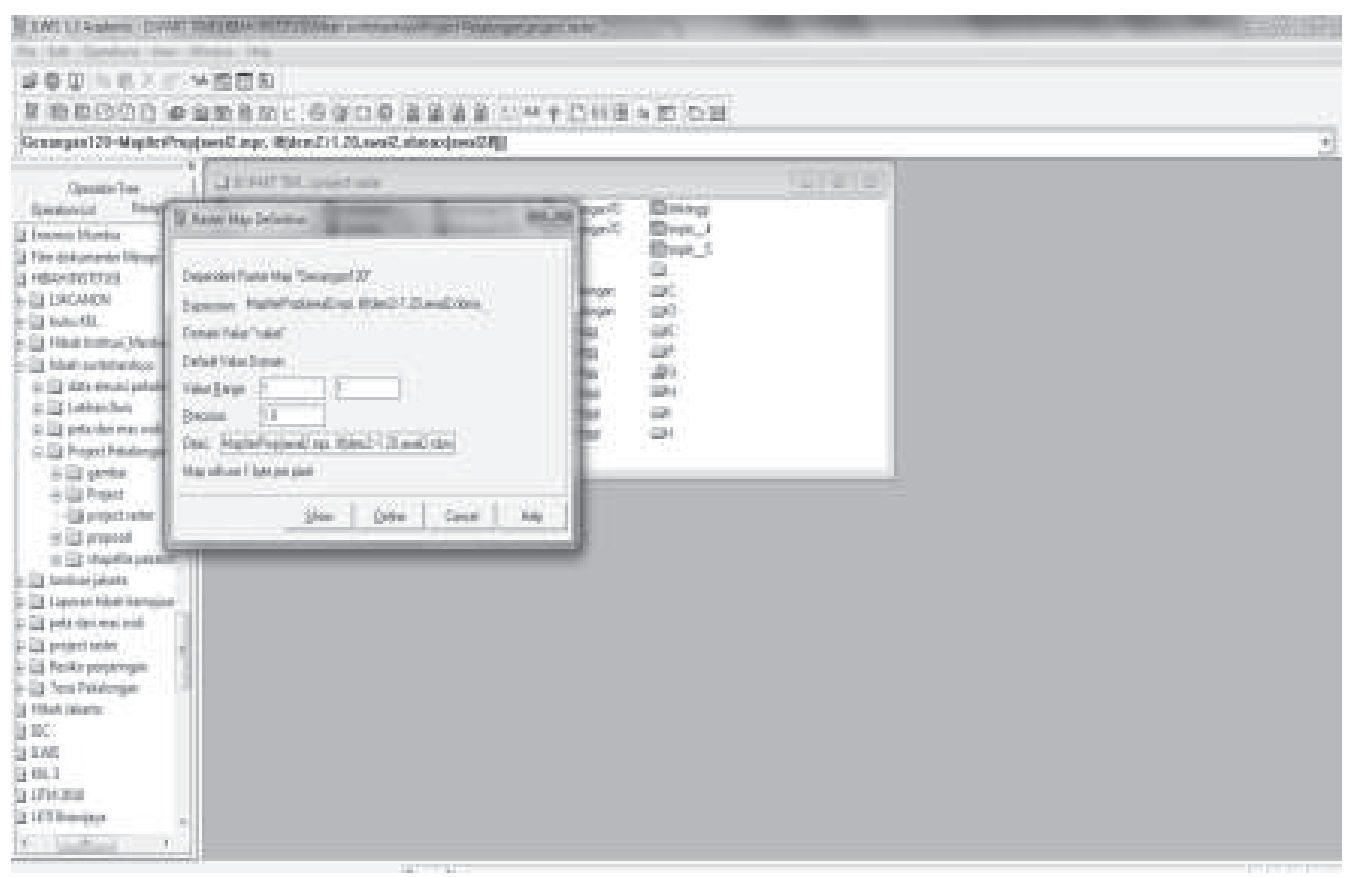

Gambar 3. Jendela Proses Iterasi pada Software ILWIS 3.3 

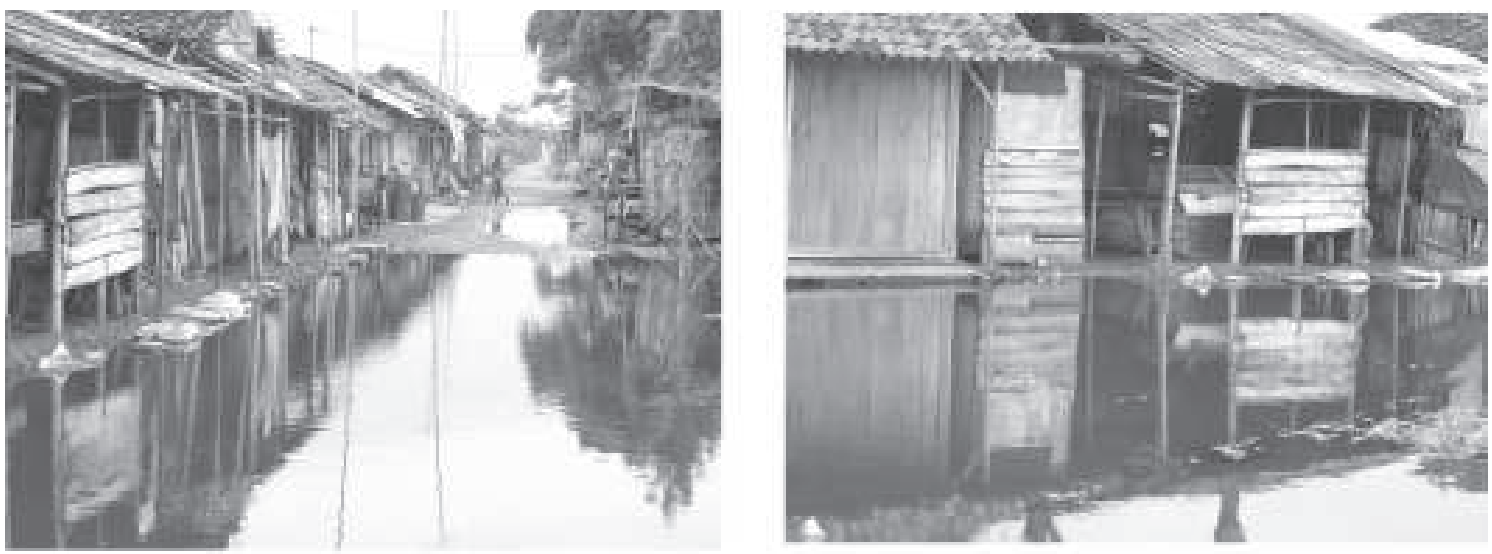

Gambar 4a. Genangan Banjir pada Ruas Jalan, 4b. Genangan Banjir di Permukiman Penduduk

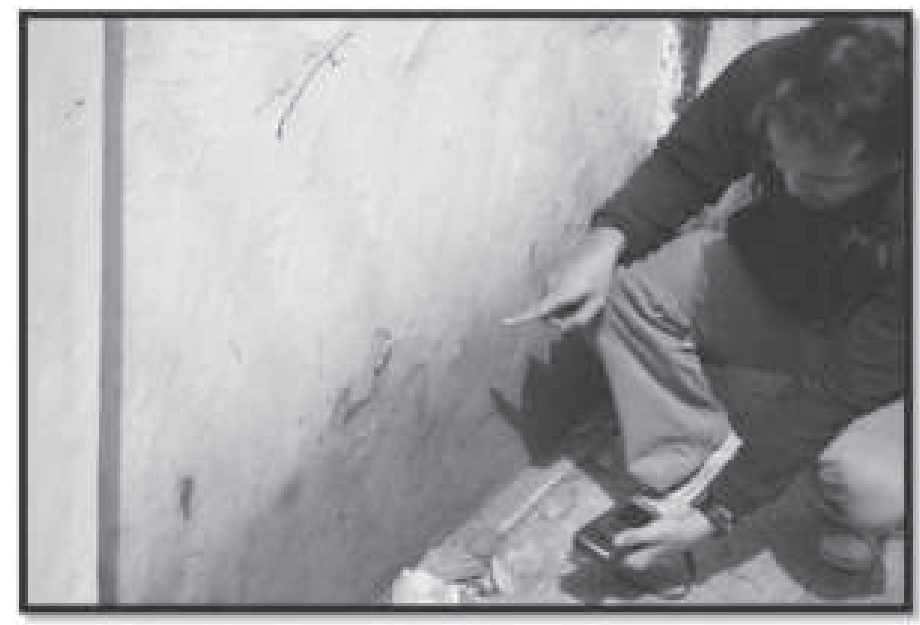

Gambar 4c. Tinggi Bekas Genangan Banjir Rob pada Dinding Rumah Penduduk (Foto Nirwansyah 2012)

Banjir rob di Pekalongan hampir terjadi setiap hari ketika air laut pasang. Berdasarkan informasi dari masyarakat setempat, kejadian ini terjadi sejak 10 tahun terakhir. Kejadian banjir rob ini terutama melanda kelurahan yang berbatasan dengan laut (Gambar 6). Berdasarkan data Dinas Kelautan dan Perikanan, pasang tertinggi di Pekalongan adalah 1,1 meter. Pemodelan genangan banjir dalam penelitian ini berdasarkan skenario kenaikan muka air laut. Penggunaan data pasang maksimal dimaksudkan untuk melakukan pemodelan dengan skenario terburuk untuk rencana pengelolaan pesisir. Rencana pengelolaan pesisir dengan skenario terburuk dimaksudkan agar dapat lebih wasapada dan siap dengan ancaman banjir rob yang akan datang. IPPC (2007) memprediksikan bahwa kenaikan muka air laut adalah $6 \mathrm{~mm}$ per tahun. Akumulasi tinggi pasang maksimum dan kenaikan permukaan air laut digunakan untuk melakukan pemodelan banjir genangan pada Tahun 2050. Pertimbangan ini digunakan karena untuk menyusun suatu rencana pengelolaan pesisir dibutuhkan penilaian terhadap ancaman bencana banjir rob jangka panjang. Berdasarkan rata-rata kenaikan muka air laut sebesar $6 \mathrm{~mm}$ per tahun, maka tinggi genangan maksimum banjir rob adalah 1,346 meter atau $135 \mathrm{~cm}$.

Hasil pemodelan menggunakan skenario genangan $135 \mathrm{~cm}$ menunjukkan bahwa genangan 


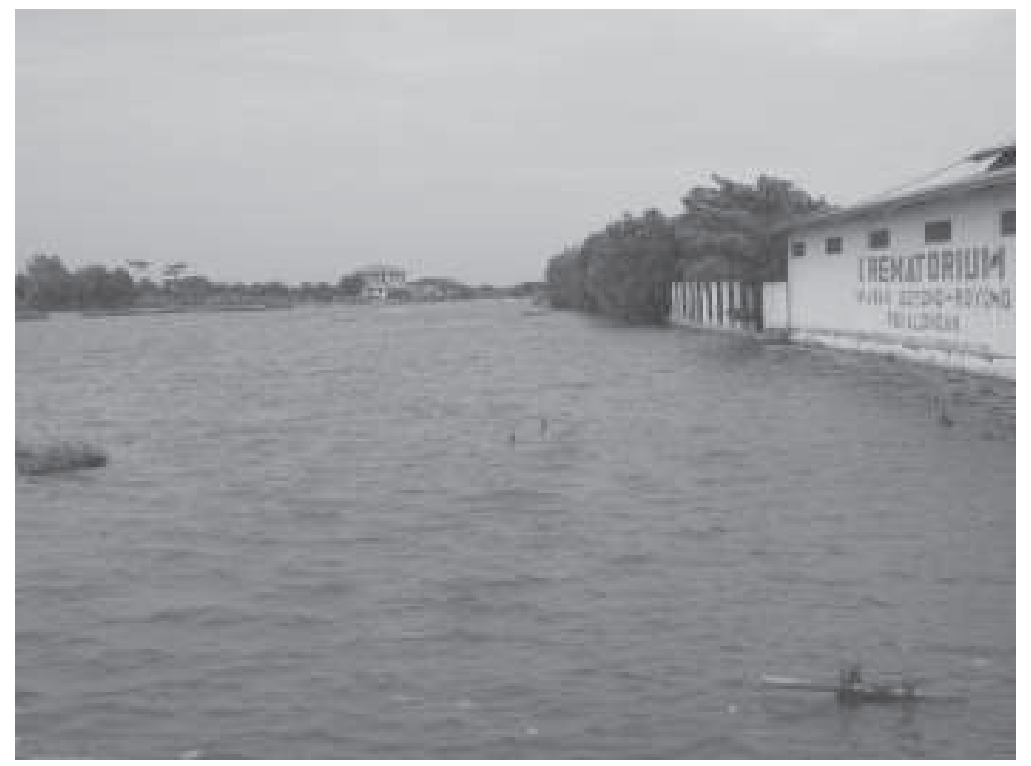

Gambar 6. Permukiman yang Berbatasan Langsung dengan Laut

banjir masuk ke daratan dengan jarak terjauh 4,7 kilometer. Luas area yang tergenang mencapai $51 \%$ dari total luas Kota Pekalongan. Peta pemodelan genangan banjir rob dengan skenario $135 \mathrm{~cm}$ disajikan pada Gambar 7.

Penelitian dengan tema yang sama pernah dilakukan oleh Nirwansyah (2012) di Pesisir Pekalongan. Perbedaaan dengan penelitian ini adalah bahwa pada penelitian tersebut menggunakan fungsi "if' pada Software Arcgis 9.3 sehingga wilayah dengan tinggi tertentu akan didefinisikan sebagai wilayah yang tergenang. Misalnya digunakan skenario genangan $20 \mathrm{~cm}$, maka wilayah penelitian yang letaknya pada ketinggian kurang dari $20 \mathrm{~cm}$ akan didefinisikan sebagai wilayah tergenang. Metode ini tidak memperhitungkan letak suatu wilayah serta keterhubungan dengan pesisir sebagai sumber banjir rob, sehingga wilayah di tengah daratan yang tidak terhubung sengan wilayah pesisir dengan ketinggian kurang dari skenario ketinggian genangan akan didefinisikan sebagai wilayah tergenang. Hal ini menyebabkan hasil yang diperoleh menjadi kurang logis dibandingkan dengan hasil yang diperoleh dari model iterasi yang digunakan pada penelitian ini. Selain itu, wilayah yang tergenang pada metode yang dihasilkan dari penelitian Nirwansyah (2012) lebih luas, karena semua wilayah dengan ketinggian kurang dari skenario ketinggian genangan didefinisikan sebagai wilayah tergenang. Penelitian ini merupakan kelanjutan dari penelitian sebelumnya yang dilakukan pada lokasi sama dan dengan lokasi sama namun dengan skenario genangan yang berbeda. penelitian tersebut dilakukan oleh Mardiatno dkk (2012) dengan menggunakan skenario pasang tertinggi, yakni dengan ketinggian $117 \mathrm{~cm}$. Berdasarkan penelitian tersebut, metode yang digunakan memiliki akurasi sebesar $87,5 \%$.

\subsection{Dampak Lingkungan Akibat Banjir Pesisir}

Pekalongan merupakan waterfront city yang berhadapan langsung dengan Laut Jawa dengan penduduk yang padat. Banjir rob yang terjadi di wilayah pesisir khususnya di Pantai Utara Jawa, telah membawa dampak signifikan terhadap aktivitas di wilayah perkotaan. Selain itu kondisi elevasi wilayah tersebut yang berada pada wilayah pesisir yang sangat datar, menyebabkan potensi kejadian banjir rob menjadi lebih besar. Berdasarkan wawancara dengan masyarakat setempat, banjir rob hampir terjadi setiap hari dengan durasi waktu genangan $2-4$ jam. Genangan seringkali terjadi di ruas jalan, sawah, halaman rumah penduduk dan beberapa fasilitas umum seperti sekolah, kantor desa dan puskesmas. Daerah yang terletak di dekat tubuh air, dalam hal ini sungai dan saluran air, mengalami genangan yang lebih dalam. 


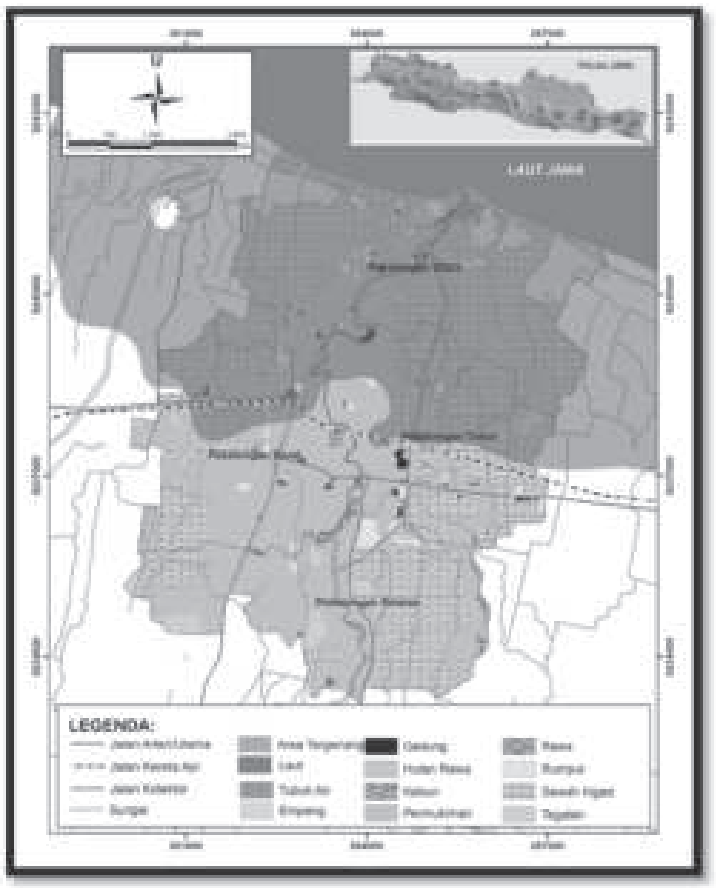

Gambar 7. Peta Pemodalan Genangan $135 \mathrm{~cm}$

Luas wilayah Kota Pekalongan sekitar $4.225 \mathrm{Ha}$ atau $0,14 \%$ dari wilayah Provinsi Jawa Tengah. Sebagian besar penggunaan lahan Kota Pekalongan merupakan permukiman dengan luas $2.333 \mathrm{Ha}$ atau sebesar $55,50 \%$ dari total luas wilayah. Lahan sawah menempati urutan kedua setelah permukiman yaitu dengan luasan $1.339 \mathrm{Ha}$ atau $32,81 \%$ dari luas total. Lahan sawah tersebut merupakan lahan sawah dengan irigasi teknis. Penggunaan lahan berupa perkebunan/tegalan memiliki luasan $75 \mathrm{Ha}$, sedangkan rawa-rawa yang tidak dimanfaatkan seluas $2 \mathrm{Ha}$. Lahan budidaya tambak banyak dijumpai di dekat pantai. Sawah yang berada di dekat tambak seringkali menjadi sawah yang tidak produktif akibat tergenang air laut. Lahan tambak memiliki luasan $329,9 \mathrm{Ha}$. Adapun peta penggunaan lahan Kota Pekalongan disajikan dalam Gambar 8. Peta penggunaan lahan disusun berdasarkan data citra GeoEye perekaman Tanggal 16 Agustus 2009.

Kawasan pesisir di Pekalongan umumnya dimanfaatkan sebagai lahan tambak. Hanya terdapat sebagian kecil wilayah permukiman di dekat pantai yang merupakan permukiman nelayan. Pada umunya kualitas permukiman nelayan relatif rendah.

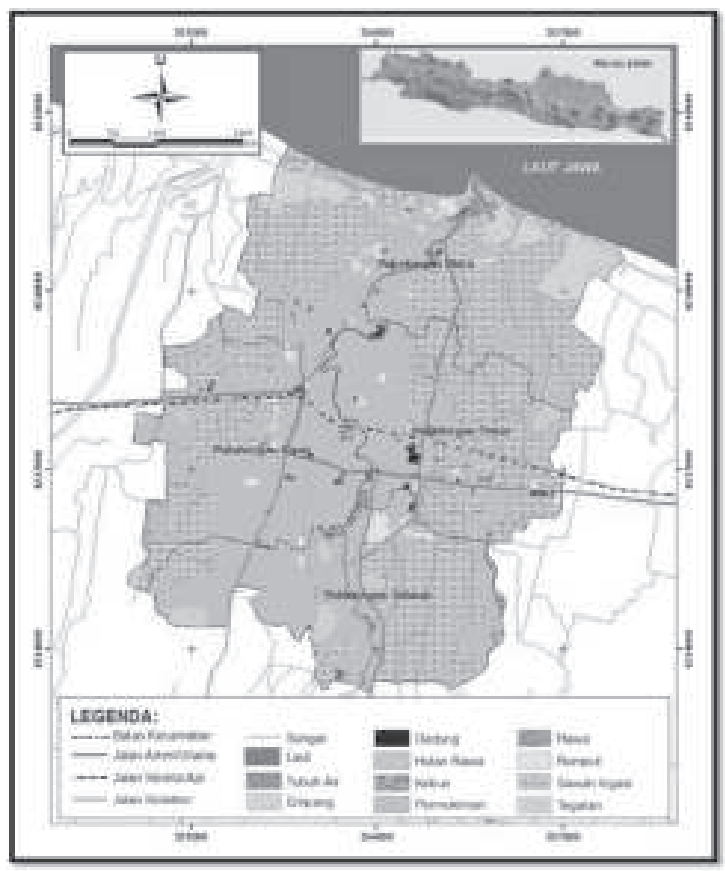

Gambar 8. Peta Penggunaan Lahan Kabupaten Pekalongan

Penggunaan lahan lain di kawasn pesisir adalah kegiatan pariwisata yang terdapat di Kelurahan Krapyak Lor, Panjang Baru, dan Panjang Wetan. Objek wisata yang ditawarkan adalah keindahan pemandangan pantai seperti Pantai Slamaran, Wisata Bahari PPNP dan Pasir Kencana.

Luas dan persentase penggunaan lahan tergenang pada skenario $135 \mathrm{~cm}$ disajikan dalam Tabel 1. Penggunaan lahan yang mengalami genangan paling luas adalah permukiman yaitu $1.295,26$ Ha. Genangan banjir pada areal permukiman dapat mengganggu aktivitas manusia dan memberikan dampak yang buruk bagi kesehatan dan kebersihan lingkungan. Sawah irigasi merupakan penggunaan lahan yang memiliki luas genangan terbesar kedua setelah permukiman, yakni seluas 506,64 Ha. Genangan banjir berpengaruh terhadap kesuburan tanah dan pertumbuhan tanaman padi. Besarnya persentase sawah yang tergenang akan mempengaruhi produktivitas pertanian di Kota Pekalongan yang pada akhirnya dapat mengancam ketahanan pangan. Penggunaan lahan tambak dan hutan rawa merupakan lahan yang tergenang seluruhnya pada skenario genangan $135 \mathrm{~cm}$. Hal ini 

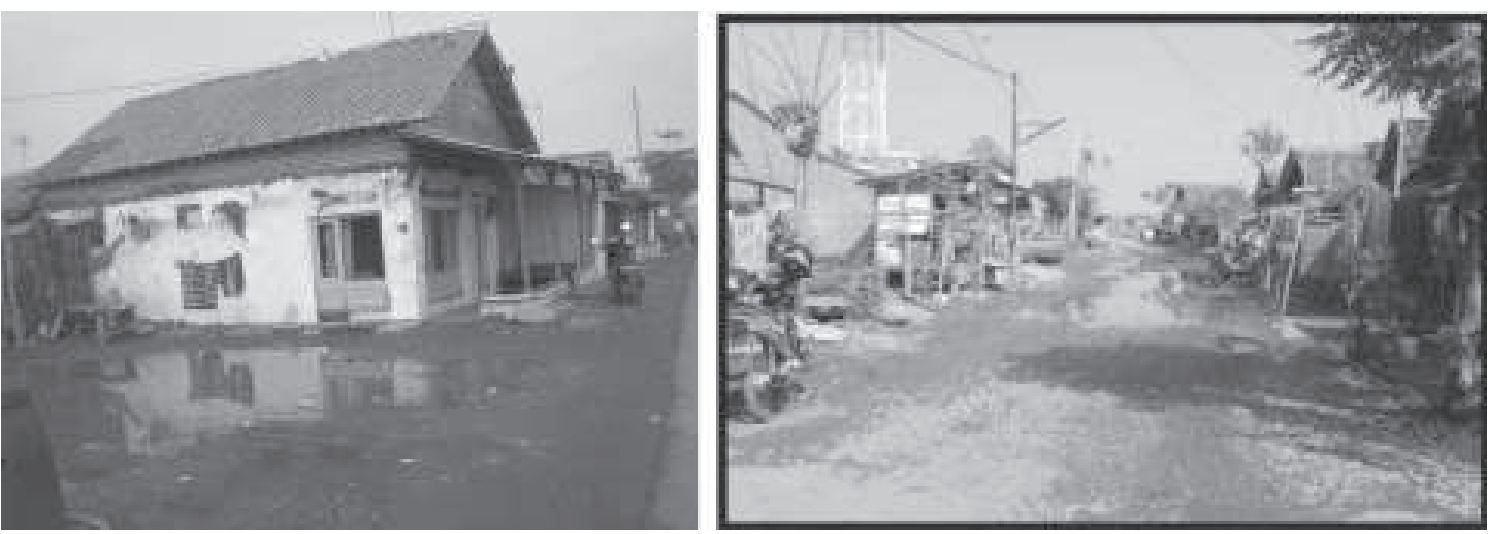

Gambar 9. A) Kerusakan bangunan rumah akibat genangan banjir, dan b) Kerusakan ruas jalan akibat genangan banjir (Foto Nirwansyah, 2012)

dikarenakan lahan tambak dan hutan rawa terletak dekat dengan pantai sehingga memiliki potensi yang sangat besar terhadap banjir genangan.

Banjir rob menyebabkan banyak kerusakan pada infrastruktur. Banyak bangunan mengalami kerusakan ataupun penurunan kualitas dikarenakan tidak dapat bertahan dengan genangan air laut yang masuk ke daratan. Permukiman, jalan, sawah, tambak, industri serta jalan di wilayah Pekalongan Utara cukup terkena dampak banjir pasang (Gambar 9a dan Gambar 9b). Kerusakan infrastruktur memberikan kerugian yang besar bagi masyarakat. Aktivitas masyarakat menjadi terganggu akibat adanya

Tabel.1 Luas Penggunaan Lahan yang Tergenang pada Skenario Tinggi Genangan $135 \mathrm{~cm}$

\begin{tabular}{lr}
\hline Penggunaan Lahan & Luas Genangan(Ha) \\
\hline Sawah irigasi & 506,64 \\
Tubuh air & 80,51 \\
Empang/tambak & 229,97 \\
Gedung & 8,40 \\
Rumput & 40,40 \\
Permukiman & 1295,26 \\
Hutan rawa & 1,65 \\
Kebun & 1,95 \\
Tegalan & 6,43 \\
\hline TOTAL & $\mathbf{4 . 2 2 5 , 0 0}$ \\
\hline
\end{tabular}

Sumber: Analisis Data, 2013 kerusakan terhadap infrastruktur.

Infrastruktur lain yang mengalami kerusakan cukup besar adalah sanitasi. Wilayah pesisir Kota Pekalongan yang sebagian besar merupakan daerah permukiman, dilengkapi sanitasi untuk mendukung aktivitas kehidupan masyarakat. Beberapa diantaranya merupakan sanitasi terbuka, dan sebagian lainnya merupakan sanitasi tertutup. Sebagai kota industri, sanitasi juga diperlukan untuk menyalurkan limbah yang dihasilkan ke sistem drainase perkotaan. Kondisi demikian cukup berdampak pada kualitas air sungai, dan selokan di Pekalongan. Selain itu, belum ada standarisasi pengolahan limbah industri baik kecil ataupun besar di Kota Pekalongan.

Umumnya wilayah pesisir Pekalongan dimanfaatkan oleh masyarakat sebagai lahan budidaya tambak. Namun genangan banjir mengakibatkan lahan tambak mengalami kerusakan dan penurunan produktivitas. Kondisi perairan di muara sungai menjadi tercemar akibat adanya genangan banjir. Penurunan produktivitas lahan tambak dikarenakan kondisi perairan sudah tidak sesuai lagi dengan syarat hidup ikan maupun udang budidaya. Luas kerusakan lahan tambak disajikan dalam Tabel 2. Produksi perikanan di Kota Pekalongan baik secara kualitas dan kuantitas terpengaruh kondisi banjir. Penurunan kuantitas perikanan menyebabkan penurunan kuantitas pula di industri pengolahan, seperti pengasinan ikan, pengawetan ikan, dan juga ikan segar. Perubahan produksi perikanan disajikan dalam Tabel 3. 
Muh Aris Marfai, dkk. : Pemodelan Spasial Bahaya Banjir Rob Berdasarkan Skenario.....

Tabel 2. Luas Kerusakan Lahan Tambak di Kota Pekalongan Tahun 2009

\begin{tabular}{lccc}
\hline Kelurahan & $\begin{array}{c}\text { Totak Luas } \\
\text { Tambak(Ha) }\end{array}$ & $\begin{array}{c}\text { Total Luas Tambak } \\
\text { Rusak Akibat Genangan } \\
\text { Banjir (Ha) }\end{array}$ & $\begin{array}{c}\text { Persentase } \\
\text { kerusakan (\%) }\end{array}$ \\
\hline Bandengan & 69,00 & 60,00 & 87,00 \\
Kandang & 34,09 & 20,00 & 58,70 \\
Panjang & 25,33 & 25,00 & 98,70 \\
Panjang Baru & 82,10 & 15,00 & 18,30 \\
Krapyak Lor & 86,45 & 35,00 & 40,50 \\
Degayu & & & \\
\hline TOTAL & $\mathbf{2 9 6 , 9 7}$ & $\mathbf{1 8 5 , 0 0}$ & \\
\hline
\end{tabular}

Sumber: Dinas Kelautan dan Perikanan Kota Pekalongan, 2009

Tabel 3. Perubahan Produktivitas Perikanan di Kota Pekalongan Tahun 2000-2009

\begin{tabular}{crr|r|r}
\hline Tahun & Produksi (Kg) & Variansi (\%) & \multicolumn{1}{c}{ Produksi (Rp) } & Variansi (\%) \\
\hline 2000 & 64.719 .796 & 151.727 .816 .000 & \\
2001 & 71.550 .645 & $-28,0 \%$ & 165.815 .071 .000 & $30,6 \%$ \\
2002 & 51.525 .393 & $6,7 \%$ & 168.376 .130 .000 & $-19,7 \%$ \\
2003 & 54.956 .430 & $6,9 \%$ & 180.942 .958 .000 & $1,5 \%$ \\
2004 & 58.748 .281 & $-26,5 \%$ & 177.205 .561 .000 & $7,5 \%$ \\
2005 & 43.159 .882 & $-26,0 \%$ & 150.522 .629 .000 & $-2,1 \%$ \\
2006 & 31.942 .782 & $-8,5 \%$ & 131.324 .500 .000 & $-15,1 \%$ \\
2007 & 29.220 .462 & $-21,3 \%$ & 145.579 .177 .000 & $-12,8 \%$ \\
2008 & 22.998 .422 & $7,8 \%$ & 133.771 .818 .000 & $10,9 \%$ \\
2009 & 24.781 .937 & $-8,7 \%$ & & $-8,1 \%$ \\
\hline Rata-rata varian si & & & $0,2 \%$ \\
\hline
\end{tabular}

Sumber: Din as Kelautan dan Perikan an Kota Pekalongan, 2009

Genangan banjir juga melanda lahan pertanian khususnya sawah. Lahan pertanian sawah yang tergenang banjir menjadi tidak produktif lagi dan ditinggalkan oleh pemiliknya. Lahan tersebut tidak dimanfaatkan lagi oleh pemiliknya dan menjadi lahan rawa (Gambar 10). Hal ini akan berpengaruh terhadap produktivitas padi sebagai bahan pangan. Sawah yang tergenang ditinggalkan pemiliknya karena sudah tidak dapat dimanfaatkan lagi sebagai. Berdasarkan RTRW Kota Pekalongan lahan sawah tidak diperbolehkan untuk dikonversi menjadi lahan tambak. Hal ini menjadikan sebuah tantangan untuk melakukan perencanaan pengelolaan pesisir di masa yang akan datang.

Air laut yang terlalu lama menggenang di permukaan tanah akan mempengaruhi kesuburan tanah dan sifat tanah. Genangan air laut dapat meningkatkan salinitas tanah pada daerah genangan. Hal ini akan berakibat pada penurunan kesuburan tanah sehingga tidak dapat dimanfaatkan lagi sebagai 


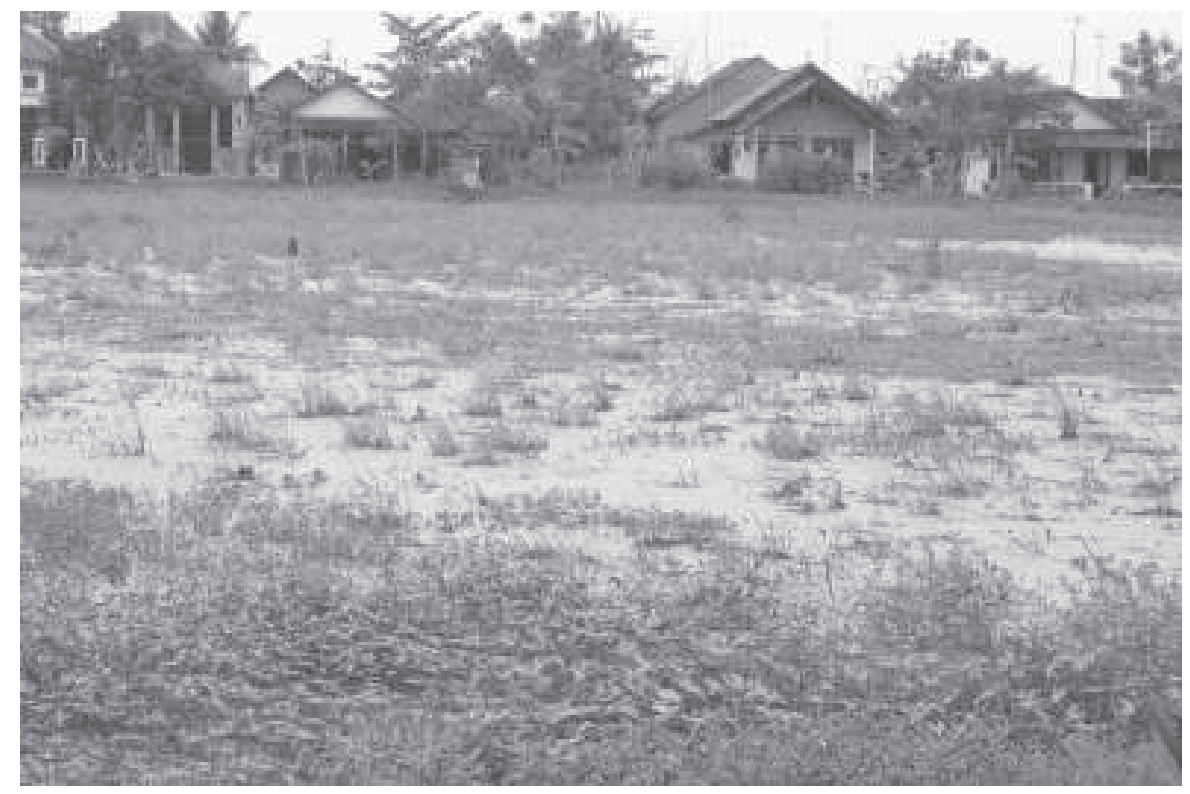

Gambar 10. Sawah yang Tergenang Banjir dan Menjadi Lahan Rawa

lahan budidaya pertanian. Lahan sawah yang mengalami genangan banjir menjadi tidak produktif lagi dan berdampak pada penurunan produktivitas pertanian.

Genangan banjir juga memberikan dampak pada sumberdaya air di pesisir Pekalongan. Air laut pasang masuk ke sungai atau saluran air yang berhubungan langsung dengan laut. Peningkatan salinitas terjadi muara sungai dan saluran air yang teraliri air laut. Airtanah di pesisir Pekalongan tergolong dalam airtanah dataran pantai dengan material akuifer berupa alluvium dan endapan pantai. Airtanah dengan material tersebut dapat dengan air laut yang masuk ke darat dan menggenang dalam waktu yang lama. Gambar 11 memperlihatkan kondisi sumur dan kamar mandi yang rusak akibat genangan rob dalam waktu yang lama.

\subsection{Perencanaan Pengelolaan Pesisir Pekalongan \\ Berbasis Pengurangan Risiko Bencana Banjir Rob}

Berkaitan dengan zonasi kawasan rawan bencana, pemerintah Kota Pekalongan telah menuangkan hal tersebut dalam rencana tata ruang wilayah mengenai Ketentuan Peraturan Zonasi untuk kawasan bencana banjir rob. Peraturan tersebut tertuang dalam Pasal 65 ayat (1) yaitu: a. kegiatan yang diperbolehkan adalah kegiatan pembangunan ruang terbuka hijau, polder, kolam retensi, stasiun rumah pompa, tanggul, saluran drainase dan prasarana perkotaan lain; b. kegiatan yang diperbolehkan bersyarat adalah kegiatan pembangunan yang tidak merusak system drainase setempat dan dapat beradaptasi dengan permasalahan rob, serta pembangunan ruang terbuka non hijau yang dapat memperbanyak infiltrasi air permukaan ke dalam tanah; c. kegiatan yang diperbolehkan terbatas adalah kegiatan pembangunan permukiman dengan mempertimbangkan kelestarian kawasan dan daya dukung lingkungan; d. kegiatan yang dilarang adalah kegiatan dan atau pembangunan yang mengancam kerusakan dan atau menurunkan kualitas sanitasi lingkungan; dan e. penetapan batas dataran rob dilakukan oleh instansi yang berwenang.

Permukiman merupakan penggunaan lahan yang mengalami genangan banjir paling luas akibat banjir rob. Hal ini dikarenakan lokasi permukiman yang terlalu dekat dengan garis pantai. Upaya pengelolaan yang dapat dilakukan untuk mengurangi risiko bencana banjir adalah dengan beradaptasi dengan adanya banjir pesisir tersebut. Cara adaptasi yang telah banyak dilakukan oleh masyarakat adalah dengan meninggikan lantai rumah ataupun 


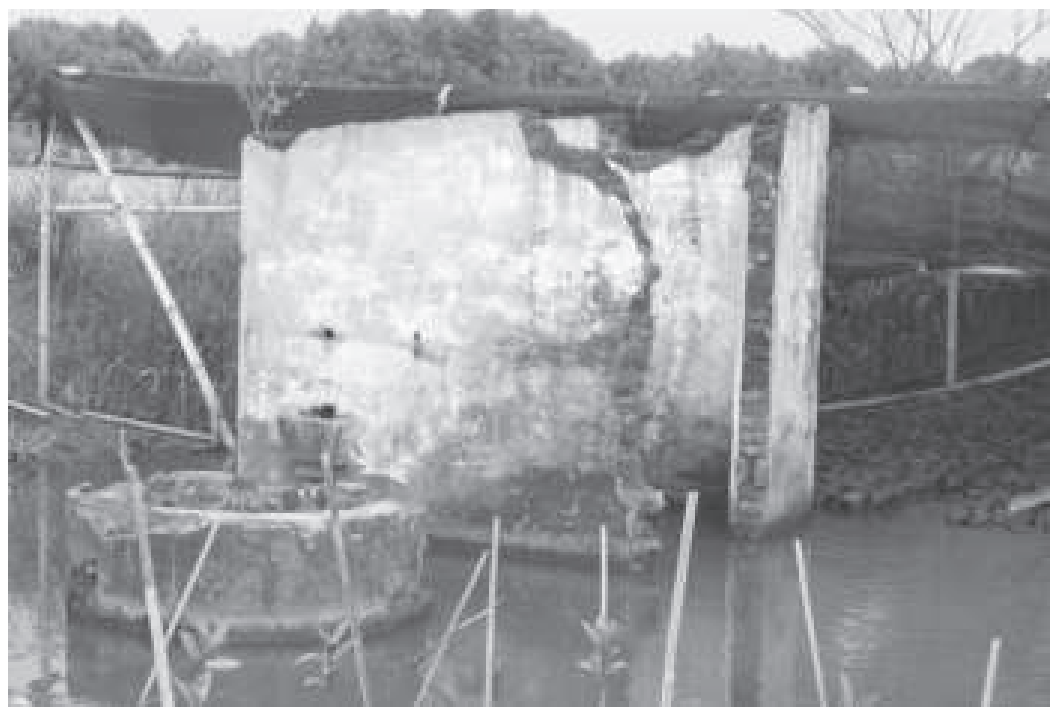

Gambar 11. Fasilitas Sumur dan Kamar Mandi yang Mengalami Genangan di Sekitarnya (Foto Nirwansyah, 2012)

membangun rumah menjadi bertingkat. Hal ini dilakukan masyarakat untuk melindungi rumah dari genangan banjir. Berdasarkan Ketentuan Peraturan Zonasi yang tertuang dalam RTRW, maka upaya yang mungkin dilakukan terkait dengan banjir pesisir adalah upaya konservasi. Penanaman tanaman pekarangan di sekitar rumah diharapkan dapat membantu percepatan infiltrasi di daerah genangan banjir. Varietas tanaman yang dapat bertahan hidup di air asin diperlukan untuk mewujudkan upaya ini.

Luasnya sawah irigasi yang tergenang banjir memberikan dampak ekonomi yang besar bagi petani di kawasan pesisir. Oleh karena itu diperlukan upaya untuk mengurangi risiko yang ditimbulkan oleh banjir pesisir. Berdasarkan RTRW Kota Pekalongan, penggunaan lahan sawah tidak diperbolehkan dikonversi menjadi lahan tambak. Solusi yang mungkin diterapkan untuk mengurangi risiko bencana banjir pesisir adalah dengan memilih varietas padi yang tahan terhadap genangan air asin. Balai Besar Penelitian Tanaman Padi telah mengembangkan varietas unggul benih padi yang tahan terhadap air asin. Salah satu varietas yang dikembangkan oleh BBPTP adalah padi varietas Inpara 1. Varietas ini baik untuk ditanam di daerah rawa pasang surut. Hasil produksi varietas Inpara 1 tidak kalah dengan padi air tawar sehingga kerugian ekonomi akibat banjir pesisir dapat berkurang. Solusi ini dapat diterapkan untuk petani di kawasan pesisir
Pekalongan.

Perlindungan akan bahaya banjir pesisir secara alami dapat dilakukan dengan melakukan penanaman kembali vegetasi mangrove. Mangrove secara alami dapat melindungi pantai dari abrasi dan banjir pesisir. Penanaman mangrove di sepanjang pesisir Pekalongan telah dicantumkan dalam Peraturan Daerah Kota Pekalongan tentang RTRW yaitu mengenai kawasan konservasi pantai. Kawasan konservasi yang diperuntukkan bagi pengembangan mangrove dan terumbu karang seluas 80 ha meliputi Kelurahan Bandengan, Kelurahan Kandang Panjang, Kelurahan Panjang Baru, dan Kelurahan Degayu di Kecamatan Pekalongan Utara.

\section{Simpulan}

Pemodelan genangan banjir dapat dilakukan dengan menggunakan prediksi kenaikan air laut IPCC 2007. Hal ini dilakukan untuk mendapatkan skenario terburuk untuk merumuskan rencana pengelolaan pesisir di masa yang akan datang. Area genangan yang paling luas pada skenario genangan $135 \mathrm{~cm}$ terjadi di Kecamatan Pekalongan Utara yang berbatasan langsung dengan Laut Jawa. Areal penggunaan lahan yang paling luas tergenang adalah permukiman dengan luas genangan 55,50\% dan sawah irigasi dengan luasan 32,81\%. Banjir rob berdampak besar terhadap lingkungan, antara lain kerusakan infrastruktur, kerusakan lahan pertanian 
dan tambak serta pencemaran tanah dan air. Kerusakan terjadi pada infrastruktur berupa jalan, permukiman dan sanitasi. Kerusakan lahan pertanian dan tambak dapat memberikan dampak lebih lanjut yaitu penurunan produktivitas pangan.

Rencana pengelolaan pesisir didasarkan pada permasalahan yang timbul akibat banjir pesisir dan Rencana Tata Ruang Wilayah Kota Pekalongan Tahun 2009-2029. Beberapa program yang dapat dilakukan untuk mengurangi risiko bencana banjir rob adalah dengan peninggian lantai rumah, konservasi di lingkungan permukiman, pemilihan varietas padi yang tahan air asin dan penanaman mangrove sebagai barier alami. Hal ini harus dilakukan dengan kolaborasi yang baik antara pemerintash, masyarakat dan pihak swasta, agar program dapat berjalan dengan baik dan berkelanjutan.

\section{Ucapan Terima Kasih}

Sebagian data yang digunakan dalam penelitian ini merupakan bagian dari Hibah Penelitian Unggulan Kerjasama Institusi Universitas Gadjah Mada Tahun 2012 dengan Nomor Kontrak 11/Dir.Keu/KN/DIPAUGM/2012 Tanggal: 1 Maret 2012. Terima kasih kami sampaikan kepada LPPM UGM dan pimpinan Fakultas Geografi UGM yang telah memberi kesempatan dan menfasilitasi penulis untuk melakukan penelitian ini.

\section{Daftar Pustaka}

Aerts, J.; Bowman, M.; Dircke, P.; Major, D.; dan Marfai, M.A. 2009. Connecting Delta Cities, About Global Coastal Cities and Future Chalanges. VU University Press, Amsterdam, The Netherlands.

Aldrian, E.; Karmin, M.; dan Budiman. 2011. Adaptasi dan Mitigasi Perubahan Iklim di Indonesia. Jakarta: BMKG

Blackett, P. dan Hume, T. 2007. Community Involvement in Coastal Hazard Mitigation: Some Insight into Process and Pitfalls. Paper disampaikan dalam seminar Politics of Planning Conference 2007. New Zealand Planning Institute.

Burrough P.A. dan McDonnell R.A. 1998. Principals of Geographical Information System. Oxford University Press, New York.

Bryan, B.; Harvey, N.; Belerio, T. dan Bourman, B. 2001. "Distributed process modeling for regional assessment of coastal vulnerability to sea level rise". Environmental Modeling and Assessment, 6, 57-65.

Christanto, J. 2010. Pengantar Pengelolaan Berkelanjutan Sumberdaya Pesisir dan Pulau-Pulau Kecil. Deepublish, Yogyakarta.

Demerkisen, A.C.; Evrendilek, F.; Berberoglu, S.; dan Killie, S. 2006. "Coastal flood risk analysis using landsat-7 etm+ imagery and srtm dem: a case study of Izmir, Turkey". Environmental Monitoring and Assessment, 131(1-3), 293-300.

ILWIS. 2001. Ilwis 3.0 Academic User'S Guide. ITC Enschede.

International Panel for Climate Change (IPCC). 2001. Climate Change 2001: The Scientific Basis. Cambridge University Press, Cambridge.

International Panel for Climate Change (IPCC). 2007. Climate Change 2007: The Physical Science Basis. Cambridge University Press, Cambridge.

Kesbangpol dan Linmas. 2010. Laporan Kejadian Bencana: Banjir dan Rob. Pemerintah Kota Pekalongan, Pekalongan.

Kesbangpol dan Linmas. 2011. Laporan Kejadian Bencana: Banjir dan Rob. Pemerintah Kota Pekalongan, Pekalongan.

Kobayashi, H. 2003. Vulnerability Assessment and Adaptation Strategy to Sea-Level Rise in Indonesian Coastal Urban Areas. National Institute for Land and Infrastructure Management, Japan.

Kraas, F. 2007. "Megacities and global change: key priorities". Geographical Journal, 173 (1), 79-82.

Kresch, D.L.; Mastin, M.C. dan Olsen, T.D. 2002. Fifty-Year Flood-Inundation Maps for Olanchito, Honduras. Tacoma, Washington, USA, US Geological Survey.

Kumar, D.P.K. 2006. Potential Vulnerability Implications of Sea Level Rise for The Coastal Zones of Chocin, Southwest Coast of India. Environmental Monitoring and Assessment, 123, 333-344.

Mardiatno, D. 2007. "Kajian spasio-temporal kejadian bencana alam periode 1907-2006 di indonesia”. Jurnal Kebencanaan Indonesia, 1(3), 151 - 160. 
Mardiatno, D.; Sunarto; Rahayu, W.F.L. dan Stötter, J. 2007a. "Misconception of run-up definition and its implication to tsunami risk assessment, a case study in pacitan coastal area, indonesia". Indonesian Journal of Geography, 39(2), 185-201.

Mardiatno, D.; Sunarto dan Stötter, J. 2007b. Tsunami Risk in Relation to The Built-up Area Vulnerability in Pacitan Municipality, East Java-Indonesia. Makalah dalam International Association of Geomorphologists (I.A.G) Conference for South-east Asia Region, 25-29 Juni 2007.

Mardiatno, D.; Widjo K.; Lavigne, F.; Sunarto dan Stoetter, J. 2008a. GIS Application for Tsunami Risk Assessment in Cilacap, South Java-Indonesia. Prosiding International Conference on Tsunami Warning (ICTW), 12-14 November 2008.

Mardiatno, D.; Sutikno; Sunarto; Lavigne, F. dan Stötter, J. 2008b. The Impact of Java Tsunami $17^{\text {th }}$ July 2006 to The South Coast of Java Island-Indonesia. dalam Umitsu, M. and M. Takahashi (eds). Geomorphological Comparative Research on Natural Disaster Mitigation in the Coastal Regions of Tropical Asia. Prosiding dalam Phuket, Ho Chi Minh, and Pattaya Conferences. JSPS Asia and Africa Science Platform Program, Nagoya University (Japan).

Mardiatno, D.; Marfai, M.A.; dan Sartohadi, J. 2009. Multi-Risks of Disasters in Cilacap City, Indonesia. Prosiding dalam International Coastal Conference. Nagoya Japan, 23-25 Februari 2009. Hal: 1-14.

Mardiatno, D.; Purnama, Ig. L. S.; Marfai, M.A.; Hadmoko, D.S.; Prihatno, H. 2012. Analisis Bencana untuk Pengelolaan Pesisir Terpadu: Studi Kasus Banjir Pesisir di Pekalongan. Laporan Penelitian. Hibah Penelitian Unggulan Kerjasama Institusi Universitas Gadjah Mada Tahun 2012

Marfai, M.A. 2003. GIS Modeling of River and Tidal Flood Hazards in A Waterfront City: Case Study, Semarang City, Central Java, Indonesia. M.Sc. Thesis. ITC, Enschede, The Netherlands.

Marfai, M.A. 2004. "Tidal flood hazard assessment: modeling in raster gis, case in western part of semarang coastal area". Indonesian Journal of Geography, 36(1), 25-38.

Marfai, M.A. dan King, L. 2008a. "Tidal inundation mapping under enhanced land subsidence in Semarang, Central Java Indonesia”. Environmental Geology, 55, 1507-1518.

Marfai, M.A.; King, L.; Sartohadi, J.; Sudrajat, S.; Budiani, S.R. dan Yulianto, F. 2008. "The impact of tidal flooding on a coastal community in Semarang, Indonesia". Environmentalist, 28, 237-248.

Marfai, M.A.; Yulianto, F.; Hizabron, D.R,; Ward, P. dan Aerts. 2009. Preliminary Assessment and Modeling The Effects of Climate Change on Potential Coastal Flood Damage in Jakarta. Laporan Kerjasama Penelitian. Vree University Amsterdam dan Universitas Gadjah Mada.

Marfai, M.A. 2011. "The hazard of coastal erosion in Central Java Indonesia: an overview". GEOGRAFIA, Malaysia Journal of Society and Space, 7(3), $1-9$.

Mills, J.P.; Buckley, S.J.; Mitchell, H.L.; Clarke, P.J. dan Edwards, S.J. 2005. “A geomatics data integration technique for coastal change monitoring". Earth Surface Processes and Landforms, 30, 651-664.

Nicholls, J.R. dan Mimura, N. 1998. "Regional issues raised by sea-level rise and their policy implications". Climate Research, 11, 5-18.

Nirwansyah, A.W. 2012. Damage Exposure Estimation Due To Coastal Flood and Sea Level Rise in Pekalongan Municipal Using Participatory GIS Method to Support Spatial Planning. M.Sc. Thesis. International Master Program on Planning and Management of Coastal Area and Watershed, Fakultas Geografi Universitas Gadjah Mada Yogyakarta.

Prihatno, H. 2011. Identifikasi dan Pemetaan Dampak Banjir Pesisir: Studi Kasus Wilayah Pesisir Pekalongan Jawa Tengah. Tesis. Magister Perencanaan Pengelolaan Pesisir dan Daerah Aliran Sungai (MPPDAS) Fakultas Geografi Universitas Gadjah Mada.

Purnama, IGL.; Marfai, A.; Hadmoko, DS.; Mutaqin, B.W. 2012. Pemodelan banjir rob dengan skenario kenaikan muka air laut akibat perubahan iklim global: Integrasi teknologi sistem informasi geografis berbasis raster dan remote sensing untuk studi kota pesisir Jakarta. Laporan Penelitian. Hibah Multidisiplin DIKTI 2012.

Ward P.; Marfai M.A.; Tobing, A.; Elings, C. 2009. Jakarta. dalam Dircke, P.; Aerts, J; Molenaar, A. (eds). Connecting Delta Cities, Sharing Knwoledge and Working on Adaptation to Climate Change. City of Rotterdam, Rotterdam, The Netherland.

Ward P.J.; Marfai, M.A.; Yulianto F.; Hizbaron, D.R.; dan Aerts, J.C.J.H. 2010. "Coastal inundation and damage exposure estimation: a case study for Jakarta”. Natural Hazards, 56, 899-916. 